\title{
REAKSI PENANGKAPAN ENERGI DAN REAKSI FIKSASI CARBON SEBAGAI ISTILAH ALTERNATIF PENGGANTI REAKSI GELAP DAN TERANG DALAM PROSES FOTOSINTESIS.
}

\author{
Oleh \\ SULARNO \\ Staf Pengajar FKIP-Biologi UISU Medan
}

\begin{abstract}
Abstrak
Dua istilah gelap dan terang dalam proses fotosisntesis seringkali menimbulkan salah persepsi dalam proses pembelajaran. Istilah ini muncul karena dua tahapan proses fotosintesis yaitu reaksi terang (karena memerlukan cahaya) dan reaksi gelap ( (tidak memerlukan cahaya tetapi memerlukan karbon dioksida). Untuk menghindari persepsi yang salah maka ada istilah alternatif yang dapat digunakan yaitu Reaksi penangkapan energi (the energy capturing reaction) untuk mengganti istilah reaksi terang. Proses ini diawali dengan penangkapan foton oleh pigmen sebagai antena, dan Reaksi fiksasi carbon (the fixation of carbon reaction) yaitu pada siklus Calvin yang mengikat karbon dioksida (the fixation of carbon) untuk membentuk ribulosa (dan kemudian menjadi gula seperti glukosasa) untuk mengganti istilah reaksi gelap. Dua istilah alternatif ini menggambarkan proses reaksi yang terjadi pada fotosintesis.
\end{abstract}

\section{PENDAHULUAN}

Fotosintesis merupakan proses pemanfaatan energi matahari oleh tumbuhan hijau yang terjadi pada kloroplast. Dalam fotosintesis terdapat dua tahap, yaitu reaksi terang dan reaksi gelap (siklus Calvin). Reaksi terang terjadi pada grana (granum), sedangkan reaksi Calvin terjadi di dalam stroma. Dalam reaksi terang, terjadi konversi energi cahaya menjadi energi kimia dan menghasilkan oksigen $\left(\mathrm{O}_{2}\right)$. Sedangkan dalam siklus Calvin terjadi seri reaksi siklik yang membentuk gula dari bahan dasar $\mathrm{CO}_{2}$ dan energi (ATP dan NADPH). Energi yang digunakan dalam siklus Calvin diperoleh dari reaksi terang.

Istilah gelap dan terang ( light and dark reactions) seringkali membuat persepsi yang salah. Pada pembelajar pemula sering salah paham bahwa reaksi gelap terjadi pada malam hari dan reaksi terang terjadi pada siang hari. Padahal fotosintesis hanya terjadi pada siang hari. Dua tahapan fotosintesis yang melatarbelakangi penggunaan istilah tersebut adalah 1. tahapan bergantung cahaya (light dependent stage) yang kemudian disebut reaksi terang (light reaction) dan 2. tahapan tidak bergantung cahaya (light independent stage). Ada baiknya jika kedua istilah tersebut diganti dengan penggambaran proses reaksi yang terjadi pada fotosintesis. Istilah terang diganti dengan reaksi penangkapan energi (the energy capturing reaction) dan istilah geiap diganti dengan reaksi fiksasi carbon (the fixation of carbon reaction)

\section{FOTOSINTESIS DAN TAHAPANNYA}

Fotosintesis adalah suatu proses biokimia yang dilakukan tumbuhan, alga, dan beberapa jenis bakteri untuk memproduksi energi terpakai (nutrisi) dengan memanfaatkan energi cahaya. Hampir semua makhluk hidup bergantung dari energi yang dihasilkan dalam fotosintesis. Akibatnya fotosintesis menjadi sangat penting 
bagi kehidupan di bumi. Fotosintesis juga berjasa menghasilkan sebagian besar oksigen yang terdapat di atmosfer bumi. Organisme yang menghasilkan energi melalui fotosintesis (photos berarti cahaya) disebut sebagai fototrof. Fotosintesis merupakan salah satu cara asimilasi karbon karena dalam fotosintesis karbon bebas dari $\mathrm{CO} 2$ diikat (difiksasi) menjadi gula sebagai molekul penyimpan energi. Cara lain yang ditempuh organisme untuk mengasimilasi karbon adalah melalui kemosintesis, yang dilakukan oleh sejumlah bakteri belerang.

\section{FOTOSINTESIS PADA TUMBUHAN}

Tumbuhan bersifat autotrof. Autotrof artinya dapat mensintesis makanan langsung. dari senyawa anorganik. Tumbuhan menggunakan karbon dioksida dan air untuk menghasilkan gula dan oksigen yang diperlukan sebagai makanannya. Energi untuk menjalankan proses ini berasal dari fotosintesis. Perhatikan persamaan reaksi yang menghasilkan glukosa berikut ini:

Daun, tempat berlangsungnya fotosintesis pada tumbuhan. $6 \mathrm{H}_{2} \mathrm{O}+6 \mathrm{CO}_{2}+$ cahaya $\rightarrow \mathrm{C}_{6} \mathrm{H}_{12} \mathrm{O}_{6}$ (glukosa) $+6 \mathrm{O}_{2}$

Glukosa dapat digunakan untuk membentuk senyawa organik lain seperti selulosa dan dapat pula digunakan sebagai bahan bakar. Proses ini berlangsung melalui respirasi seluler yang terjadi baik pada hewan maupun tumbuhan. Secara umum reaksi yang terjadi pada respirasi seluler berkebalikan dengan persamaan di atas. Pada respirasi, gula (glukosa) dan senyawa lain akan bereaksi dengan oksigen untuk menghasilkan karbon dioksida, air, dan energi kimia.

Tumbuhan menangkap cahaya menggunakan pigmen yang disebut klorofil. Pigmen inilah yang memberi warna hijau pada tumbuhan. Klorofil terdapat dalam organel yang disebut kloroplas. klorofil menyerap cahaya yang akan digunakan dalam fotosintesis. Meskipun seluruh bagian tubuh tumbuhan yang berwarna hijau mengandung kloroplas, namun sebagian besar energi dihasilkan di daun. Di dalam daun terdapat lapisan sel yang disebut mesofil yang mengandung setengah juta kloroplas setiap milimeter perseginya. Cahaya akan melewati lapisan epidermis tanpa warna dan yang transparan, menuju mesofil, tempat terjadinya sebagian besar proses fotosintesis. Permukaan daun biasanya dilapisi oleh kutikula dari lilin yang bersifat anti air untuk mencegah terjadinya penyerapan sinar matahari ataupun penguapan air yang berlebihan

\section{FOTOSINTESIS PADA ALGA DAN BAKTERI}

Alga terdiri dari alga multiseluler seperti ganggang hingga alga mikroskopik yang hanya terdiri dari satu sel. Meskipun alga tidak memiliki struktur sekompleks tumbuhan darat, fotosintesis pada keduanya terjadi dengan cara yang sama. Hanya saja karena alga memiliki berbagai jenis pigmen dalam kloroplasnya, maka panjang gelombang cahaya yang diserapnya pun lebih bervariasi. Semua alga menghasilkan olsigen dan kebanyakan bersifat autotrof. Hanya sebagian kecil saja yang bersifat heterotrof yang berarti bergantung pada materi yang dihasilkan oleh organisme lain.

\section{PROSES FOTOSINTESIS}

Hingga sekarang fotosintesis masih terus dipelajari karena masih ada sejumlah ga, dar dengan ari energi penting thap yang belum bisa dijelaskan, meskipun sudah sangat banyak yang diketahui tentang proses vital ini. Proses fotosintesis sangat kompleks karena melibatkan semua ahang ilmu pengetahuan alam utama, seperti fisika, kimia, maupun biologi sendiri. 
Pada tumbuhan, organ utama tempat berlangsungnya fotosintesis adalah da: Namun secara umum, semua sel yang memiliki kloroplas berpotensi unti melangsungkan reaksi ini. Di organei inilah tempat berlangsungnya fotosintesis tepatnya pada bagian stroma. Hasil fotosintesis (disebut fotosintat) biasanya dikirim ke jaringan-jaringan terdekat terlebih dahulu.

Pada dasarnya, rangkaian reaksi fotosintesis dapat dibagi menjadi dua bagisn utama: Reaksi penangkapan energi (the energy capturing reaction) atau reaksi terang (karena memerlukan cahaya) dan reaksi fiksasi carbon (the fixation of carbon reaction) atau reaksi gelap (tidak memerlukan cahaya tetapi memerlukar karbon dioksida).

\subsection{Reaksi penangkapan energi (the energy capturing reaction) atau reaks terang \\ Reaksi penangkapan energi (the energy capturing reaction) adalah prose:} untuk menghasilkan ATP dan reduksi $\mathrm{NADPH}_{2}$. Reaksi ini memerlukan molekul ait Proses diawali dengan penangkapan foton oleh pigmen sebagai antena.

Pigmen klorofil menyerap lebih banyak cahaya terlihat pada warna biru (400450 nanometer) dan merah (650-700 nanometer) dibandingkan bijau (500-60 nanometer). Cahaya hijau ini akan dipantulkan dan ditangkap oleh mata kita sehingge menimbulkan sensasi bahwa daun berwarna hijau. Fotosintesis akan menghasilkalebih banyak energi pada gelombang cahaya dengan panjang tertentu. Hal ini karene panjang gelombang yang pendek menyimpan lebih banyak energi.

Di dalam daun, cahaya akan diserap oleh molekul klorofil untuk dikumpuikar pada pusat-pusat reaksi. Tumbuhan memiliki dua jenis pigmen yang berfungsi akti sebagai pusat reaksi atau fotosistem yaitu fotosistem II dan fotosistem I, Fotosistem I terdiri dari molekul klorofil yang menyerap cahaya dengan panjang gelombang 680 nanometer, sedangkan fotosistem I 700 nanometer. Kedua fotosistem ini akan bekerja secara simultan dalam fotosintesis, seperti dua baterai dalam senter yang bekerja saling memperkuat.

Fotosintesis dimulai ketika cahaya mengionisasi molekul klorofil pada fotosistem II, membuatnya melepaskan elektron yang akan ditransfer sepanjang rantai transpor elektron. Energi dari elektron ini digunakan untuk fotofosforilasi yang menghasilkan ATP, satuan pertukaran energi dalam sel. Reaksi ini menyebabkan fotosistem II mengalami defisit atau kekurangan elektron yang harus segera diganti. Pada tumbuhan dan alga, kekurangan elektron ini dipenuhi oleh elektron dari hasil ionisasi air yang terjadi bersamaan dengan ionisasi kiorofil. Hasil ionisasi air ini adalah elektron dan oksigen.

Oksigen dari proses fotosintesis hanya dihasilkan dari air, bukan dari karbon dioksida. Pendapat ini pertama kali diungkapkan oleh C.B. van Neil yang mempelajari bakteri fotosintetik pada tahun 1930-an. Bakteri fotosintetik, selain sianobakteri, menggunakan tidak menghasilkan oksigen karena menggunakan ionisasi sulfida atau hidrogen.

Pada saat yang sama dengan ionisasi fotosistem II, cahaya juga mengionisasi fotosistem I, melepaskan elektron yang ditransfer sepanjang rantai transpor elektron yang akhirnya mereduksi NADP menjadi NADPH. Penangkapan energi cahaya oleh pigmen ini menjadi usulan istilah pengganti reaksi terang menjadi reaksi penangkapan energi (the energy capturing reaction)

1.2. Reaksi fiksasi carbon (the fixation of carbon reaction) atau reaksi gelap (tidak memerlukan cahaya tetapi memerlukan karbon dioksida). 
lalah daun. nsi untuk tosintesis, ya dikirim

lua bagian tau reaksi ixation of emerlukan au reaksi lah proses olekul air. biru $(400-$ $(500-600$ 1 sehingga ghasilkan ini karena

umpuikan ngsi aktif osistem II bang 680 in bekerja bekerja

fil pada ang rantai lasi yang yebabkan a diganti. dari hasil si air ini

ri karbon eil yang $\mathrm{k}$, selain ionisasi

gionisasi elektron aya oleh reaksi p (tidak yang mengikat karbon dioksida (the fixation of carbon) untuk membentuk ribulosa (dan kemudian menjadi gula seperti glukosa). Reaksi ini disebut reaksi gelap karena tidak bergantung pada ada tidaknya cahaya sehingga dapat terjadi meskipun dalam keadaan gelap (tanpa cahaya). Istilah reaksi gelap dapat diganti dengan istilah reaksi fiksasi karbon karena pada proses biokimianya terjadi fiksasi karbon dioksida untuk membentuk ribolusa.

\section{FAKTOR PENENTU LAJU FOTOSINTESIS}

Berikut adalah beberapa faktor utama yang menentukan laju fotosintesis:

1. Intensitas cahaya Laju fotosintesis maksimum ketika banyak cahaya.

2. Konsentrasi karbon dioksida Semakin banyak karbon dioksida di udara, makin banyak jumlah bahan yang dapt digunakan tumbuhan untuk melangsungkan fotosintesis.

3. Suhu

Enzim-enzim yang bekerja dalam proses fotosintesis hanya dapat bekerja pada suhu optimalnya. Umumnya laju fotosintensis meningkat seiring dengan meningkatnya suhu hingga batas toleransi enzim.

4. Kadar air

Kekurangan air atau kekeringan menyebabkan stomata menutup, menghambat penyerapan karbon dioksida sehingga mengurangi laju fotosintesis.

5. Kadar fotosintat (hasil fotosintesis)

Jika kadar fotosintat seperti karbohidrat berkurang, laju fotosintesis akan naik. Bila kadar fotosintat bertambah atau bahkan sampai jenuh, laju fotosintesis akan berkurang.

6. Tahap pertumbuhan

Penelitian menunjukkan bahwa laju fotosintesis jauh lebih tinggi pada tumbuhan yang sedang berkecambah ketimbang tumbuhan dewasa. Hal ini mungkin dikarenakan tumbuhan berkecambah memerlukan lebih banyak energi dan makanan untuk tumbuh.

\section{KESIMPULAN}

Fotosintesis merupakan proses pemanfaatan energi matahari oleh tumbuhan hijau yang terjadi pada kloroplast. Dalam fotosintesis terdapat dua tahap, yaitu reaksi terang (karena memerlukan cahaya) dan reaksi gelap ( (tidak memerlukan cahaya tetapi memerlukan karbon dioksida).. Reaksi terang terjadi pada grana (granum), sedangkan reaksi Calvin terjadi di dalam stroma.

Untuk menghindari kesalahan persepsi dengan istilah gelap-terang maka ada istilah alternative yang bisa membantu memudahkan memahami proses fotosintesis yaitu Keaksi penangkapan energi (the energy capturing reaction) Proses ini diawali dengan penangkapan foton oleh pigmen sebagai antena, dan Reaksi fiksasi carbon (the fixation of carbon reaction) yaitu pada siklus Calvin yang mengikat karbon dioksida (the fixation of carbon) untuk membentuk ribulosa (dan kemudian menjadi gula seperti glukosa) untuk mengganti istilah reaksi gelap.

\section{DAFTAR PUSTAKA}


Curtis, Helena. 1984. Biology. Fourth edition. Worth Publishers, Inc. 444 Avenue South New York 10016

Govindjee, and Rajni Govindjee. 1974. The Primary Event of Photosynthesis. Scientific America

Kimball, J.W. 1983. Biologi Jilid I. Erlangga Jakarta. 